Relations industrielles

Industrial Relations

\title{
The Nature of Human Conflict, edited by Elton B. McNeil, Prentice-Hall, Inc., Englewood Cliffs, N.J., 1965. 315 pages.
}

Alan Barrett

Volume 21, numéro 4, 1966

Congrès de l'ICRRI - 1966

1966 - CIRRI Annual Convention

URI : https://id.erudit.org/iderudit/027746ar

DOI : https://doi.org/10.7202/027746ar

Aller au sommaire du numéro

Éditeur(s)

Département des relations industrielles de l'Université Laval

ISSN

0034-379X (imprimé)

1703-8138 (numérique)

Découvrir la revue

Citer ce compte rendu

Barrett, A. (1966). Compte rendu de [The Nature of Human Conflict, edited by

Elton B. McNeil, Prentice-Hall, Inc., Englewood Cliffs, N.J., 1965. 315 pages.]

Relations industrielles / Industrial Relations, 21(4), 660-660.

https://doi.org/10.7202/027746ar

Tous droits réservés @ Département des relations industrielles de l'Université Laval, 1966
Ce document est protégé par la loi sur le droit d'auteur. L'utilisation des services d'Érudit (y compris la reproduction) est assujettie à sa politique d'utilisation que vous pouvez consulter en ligne.

https://apropos.erudit.org/fr/usagers/politique-dutilisation/ 
souligne que pour la plupart des Américains, lo libre concurrence est depuis longtemps un concept davantage politique qu'économique. Et il écrit finalement que l'action contre les combines est devenue une technique après avoir été une idéologie.

Au chapitre suivant, The New Place of Business \&, Earl F. Cheit se demande pourquoi les dirigeants d'entreprise s'intéressent outant ò la responsabilité sociale. Certains critiques prétendent qu'on n'a pas trouvé de substitut opératoire à la maximisation du profit au bénéfice des actionnaires; d'autres affirment que les dirigeants veulent légitimer leur pouvoir qui ne découle pas de la propriété par la responsabilité sociale.

Pour sa part Paul A. Somuelson, dans le chapitre six intitulé a Personal Freedoms and Economic Freedoms in the Mixed Economy », distingue deux notions de capitalisme, l'an-' cienne axée sur la maximisation du profit et la nouvelle «managerial capitalism $\gg$. L'auteur fait remarquer entre autres choses que le degré de concentration de la propriété parmi différentes corporations influence peu leur comportement.

Dans le dernier chapitre, on peut lire deux excellents textes: I'un de Philippe De Woot intitulé «The European Business et I'autre de Gilbert M. Sauvage qui traite - The French Businessmon in His Milieu $\$$.

\section{Bertrand Belzile}

The Nature of Human Conflict, Edited by Elton B. McNeil, Prentice-Hall, Inc., Englewood Cliffs, N.J., 1965. $315^{\prime}$ pages.

A cursory examination of what is in fact a panoramic view by a number of social scientists of the problem of human conflict leads one to ask where the reader might want to focus his ottention.

Here is a text that examines human conflict by applying the tools of knowledge derived from the social sciences in such a way as to focus the readers eye on the problem now with the telescope of the sociologist, now the anthropologist and now the economist, etc.

The series of essays form a whole if viewing a priori the complexity of conflicts on the grand scale - one whishes to attempt to get to the bottom of it all. For it is clearly the editor's goal to put to work top social scientists in each of their respective disciplines and to treat a problem that heretofore has been insoluble, to soy the least. The attempt is fascinating, if perhaps a bit facile.

K. Boulding's article "The Economics of Conflicts " is perhaps the most interesting article for readers of this Journal and his usual livid mind explains with keen insight the conflict content of economics and focuses particularly on the content of the "rational of conflict in labour-management relations.

Eaton B. McNeil has compiled a list of famous enough names and concentrated social science disciplines on the types of human conflict, that the book has at least the merit of demonstrating hope that the conflicts can be resolved when sufficient onalysis are applied to their coritent.

In short, this is a text of the general reader variety, though the general reader might at least want to be a social scientist.

\section{Alan Barrett}

Blue Collar World: Studies of the American Worker, Arthur B. Shostak and William Gomberg, Prentice-Hall Inc., 1964. 616 pages.

The work presents a detailed examination of the style of life of America's blue-collar workers with a good deal of emphasis on family relationships and environments as well. The study is in fact a collection of some 61 essays by as many authors with the main emphasis being on the workers life outside of work.

Individual essays by sociologists, psychologists, psychiatrists and others on a wide variety of topics form the core of the work. A listing of some of the areas of study examined will indicate in a broad manner the scope of the work: Persistence and change in working; Class life style; The behavior and values of skilled workers; Middle-class misconceptions about lower-clcss families; Mental strain in the blue-collar family; Moral perspectives of blue-collar workers: The meaning of work...

A work designed perhaps more for the case of «.personnel managers » than industrial relations people, the studies are of particular interest to those involved in sociology, psychology and social and public health work. For as the jacket suggests: "The volume includes studies from many disciplines and ranges widely over pre 8 a.m. and past 5 p.m. areas of working class life $»$. 